\title{
AUDYT KRAJOBRAZÓW POLSKI: GENEZA I OCZEKIWANIA
}

\begin{abstract}
1. Wstęp
Krajobraz to wielkoprzestrzenne środowisko naszego życia. Jest świadectwem historii, zasobności, wiedzy i umiejętności mieszkańców danego obszaru. Wpływa na nasze samopoczucie, zainteresowania i formy aktywności. Jednak o strukturze, funkcjonowaniu i zasadach kształtowania krajobrazu większość ludzi wie bardzo niewiele. Celem niniejszego artykułu jest uzasadnienie potrzeby rejestrowania i oceny coraz większych zmian zachodzących w krajobrazach Polski oraz konieczności zwracania większej uwagi na jakość krajobrazów kształtowanych dla żyjących obecnie ludzi oraz dla przyszłych pokoleń.
\end{abstract}

\section{Krajobraz jako środowisko życia ludzi i świadectwo ich kultury}

Rozumienie i definiowanie słowa krajobraz zmieniało się wraz z rozwojem wiedzy o środowisku przyrodniczym oraz o wykorzystaniu jego zasobów i walorów przez człowieka. Jedną z pierwszych definicji krajobra$\mathrm{zu}$, stosowanych w opracowaniach naukowych, sformułował Humboldt w połowie XIX w., uznając, że „krajobraz to całościowa charakterystyka regionu Ziemi" (Humboldt, 1849, za: Chmielewski, 2012, s. 17). Ponad 100 lat później, w latach 60. XX w., Wilgat pisał:

W piśmiennictwie geograficznym używa się terminu „krajobraz” w znaczeniu jednostki terytorialnej, podobnie jak w języku niemieckim "landschaft" czy rosyjskim „łandszaft” [...]. Zgodnie z etymologią i powszechnym rozumieniem, wyraz krajobraz oznacza bardziej lub mniej typowy dla danego 
regionu widok, będący zewnętrznym wyrazem środowiska geograficznego [...]. Tak więc pojęcie „krajobraz" określa treść wewnętrzną i formę zewnętrzną zjawisk w obrębie regionu (Wilgat, 1965, s. 462).

W tym samym czasie jednak coraz liczniejsza grupa badaczy zaczęła traktować krajobraz jako przestrzenny układ powiązanych ze sobą ekosystemów. Wśród tych uczonych m.in. Walter zwracał uwagę na to, że „krajobrazy pokryte są zawiłymi, dynamicznymi układami ekosystemów, determinowanymi nie tylko kompozycją florystyczna, ale także rozmaitością, strukturą i zmiennością regionalnego klimatu, lokalnymi warunkami podłoża, interakcjami biotycznymi i modyfikującym wpływem człowieka" (Walter, 1964, s. 33). Z kolei fizjonomiczne cechy krajobrazu szczególnie eksponowali architekci i architekci krajobrazu, stojąc na stanowisku, że „krajobraz to scalony obraz środowiska naturalnego i antropogenicznego danego regionu" (Bogdanowski, 1976, s. 19). Równolegle do podejścia fizjonomicznego rozwijały się badania nad multisensoryczną percepcją krajobrazu (Bernat, 2008; Skalski, 2007; Tuan, 1979). Krajobraz multisensoryczny odbierany jest wszystkimi zmysłami: wzrokiem, zapachem, słuchem, dotykiem, a nawet smakiem. Suma rejestrowanych teraz i w przeszłości wrażeń, połączona z wiedzą i doświadczeniem, składa się na zintegrowany odbiór, ocenę i w efekcie - postępowanie obserwatora (badacza, planisty, mieszkańca, turysty itp.) w stosunku do krajobrazu (Chmielewski, 2008; Pietrzak, 1998).

Szybki, wielowątkowy rozwój nauk o krajobrazie spowodował potrzebę porządkowania coraz liczniejszych opracowań cząstkowych oraz dokonywania interdyscyplinarnej syntezy wiedzy o strukturze i funkcjonowaniu przyrodniczo-kulturowych układów przestrzennych określanych już jako systemy krajobrazowe (Moss, Milne, 1999; Pietrzak, 1998). System krajobrazowy jest to zespół elementów abiotycznych i biotycznych krajobrazu (litologia, rzeźba, klimat, wody, gleby, rośliny, zwierzęta, człowiek i skutki jego działalności), wykazujących wysoki poziom złożoności. Między zespołem komponentów krajobrazu i otoczeniem zachodzi stała wymiana energii, materii i informacji (Malinowska, Lewandowski, Harasimiuk, 2004).

Według współczesnego stanu wiedzy można przyjąć, że:

krajobraz to rozległy, skomplikowany system przestrzenny, obejmujący trzy układy hierarchiczne, wzajemnie ze sobą powiązane: abiotyczny, złożony z geokompleksów; biotyczny, zorganizowany w populacje i biocenozy pozostające $\mathrm{w}$ silnych relacjach $\mathrm{z}$ ich siedliskami, $\mathrm{w}$ wyniku których kształtują się ekosystemy i fizjocenozy; antropogeniczny, obejmujący elementy krajobrazu wytwarzane, lub przekształcane przez człowieka. System ten transformuje materię i energię oraz multisensorycznie oddziałuje na będące jego 
elementami organizmy żywe. Wizualnym efektem wspólistnienia wszystkich elementów systemu na określonym obszarze, jest swoista fizjonomia krajobrazu (Chmielewski, 2012, s. 19).

Od czasów Humboldta do drugiej połowy XX w. naukowa interpretacja terminu krajobraz ulegała więc znaczącej zmianie. Wraz z rozwojem wiedzy stopniowo narastała świadomość złożoności jego struktury i funkcjonowania oraz różnorodności sposobów fizjonomicznego oddziaływania zespołu komponentów krajobrazu na człowieka. Sukcesywnie były tworzone różne systemy klasyfikacji krajobrazów: regionalne (regionalizacja fizycznogeograficzna, geobotaniczna, przyrodniczo-leśna, kulturowa itp.) oraz typologiczne (klasyfikacja krajobrazów naturalnych, aktualnych, potencjalnych; klasyfikacja stopnia antropogenicznego przekształcenia krajobrazu itp.) (Chmielewski, 2012, 2015; Ostaszewska, 2002).

Zasadnicze znaczenie dla rozwoju badań systemów krajobrazowych miało przyjęcie przez Radę Europy i ogłoszenie w 2000 r. Europejskiej Konwencji Krajobrazowej (European Landscape Convention, 2000). Ten najważniejszy europejski dokument dotyczący ochrony i kształtowania krajobrazu definiuje go jako: „obszar, postrzegany przez ludzi, którego charakter jest wynikiem działania i interakcji czynników przyrodniczych i/lub ludzkich" (European Landscape Convention, 2000, s. 3) ${ }^{1}$. Jednocześnie w dalszej części dokumentu podkreślono m.in., że: „krajobraz stanowi ważny składnik jakości życia ludzi we wszystkich miejscach: zarówno w miastach, jak i na wsi, w obszarach o znacznym stopniu degradacji jak również w miejscach o wysokiej jakości czy uznawanych za niezwykle piękne" (European Landscape Convention, 2000, s. 3).

Każda ze stron ratyfikujących Konwencję (Polska uczyniła to w 2004 r.) zobowiązała się do:

- zidentyfikowania własnych krajobrazów na całym obszarze terytorium danego kraju;

- przeanalizowania ich charakterystyk oraz przekształcających je sił i presji;

- odnotowania zmian zachodzących w strukturze i fizjonomii krajobrazów;

- dokonania oceny zidentyfikowanychw ten sposób krajobrazów, z uwzględnieniem szczególnych wartości przypisanych im przez strony i ludność, których to dotyczy.

Przywołane zapisy Konwencji wywołały wzmożone zainteresowanie badaczy z licznych ośrodków naukowych (Cassatella, Peano, 2011; Degórski, Ostaszewska, Richling, Solon, 2014; Jones, Stenseke, 2011; Mücher, Clijn,

${ }_{1}$ Nie jest to definicja naukowa, ale formuła opracowana dla potrzeb międzynarodowego dokumentu Rady Europy, w formie przystępnej dla szerokiego kręgu odbiorców. 
Wascher, Schaminée, 2010). W wielu krajach opracowano instrukcje (przewodniki) dotyczące metod klasyfikacji i oceny współczesnych krajobrazów, a także atlasy i katalogi krajobrazów, zazwyczaj w postaci wyspecjalizowanych, bogato ilustrowanych baz danych (Bezek, Mikóls, Izakovičowá, 2010; Chmielewski, Myga-Piątek, Solon, 2015; Fairclough, Macinnes, 2003; Nague, Sala, 2006; Van Eetvelde, Antrop, 2009; Zoido, 2006).

Jednocześnie $\mathrm{w}$ wielu krajach Europy pracom tym towarzyszył rozwój systemu edukacji krajobrazowej społeczeństw. Dzięki temu coraz więcej osób zaczęło zdawać sobie sprawę, że stan krajobrazu jest odzwierciedleniem poszanowania dziedzictwa natury danego regionu oraz świadectwem kultury (historii, wiedzy i umiejętności) jego mieszańców. Co więcej, krajobraz jest podstawą kształtowania się tożsamości miejsc i regionów (Myczkowski, 2003), jakość krajobrazu zaś znacząco wpływa na samopoczucie jego użytkowników (Bernat, 2017; Chmielewski, Chmielewski, Kułak, 2019).

\section{Audyt aktualnych krajobrazów Polski - geneza, przepisy prawne i założenia metodyczne}

Krajobrazy zmieniają się w czasie - zarówno pod wpływem działania naturalnych procesów przyrodniczych (procesy tektoniczne, eoliczne, wylewy rzek, erozja, sukcesja roślinna itp.), jak i - bardziej dynamicznie - w wyniku działalności człowieka. Stosunkowo powoli zmienia się rzeźba terenu, znacznie szybciej - struktura pokrycia terenu, a najszybciej i na największą skalę - fizjonomia (wygląd) krajobrazu.

Jak wykazały badania przeprowadzone w ramach prac Komitetu Przestrzennego Zagospodarowania Kraju PAN (Chmielewski, Śleszyński, Chmielewski, Kułak, 2018) do najważniejszych procesów zachodzących w latach 1990-2012 w systemach krajobrazowych Polski (podobnie jak wielu innych krajów Europy) należą:

- spadek powierzchni biologicznie czynnej ekosystemów nieleśnych i rozdrabnianie struktury krajobrazowych systemów ekologicznych [KSE];

- upraszczanie wewnętrznej struktury i spadek różnorodności biologicznej oraz osłabienie stabilności i odporności KSE;

- terytorialna ekspansja miast i rozwój systemu barier ekologicznych. Analiza zmian struktury pokrycia terenu w Polsce, przeprowadzona na podstawie danych z systemu CORENE Land Cover z lat 1990-2012, wykazała m.in., że największe zmiany powierzchni dotyczyły (Chmielewski, Śleszyński, Chmielewski, Kułak, 2018): 
- wzrostu obszaru miejskiej zabudowy luźnej o 655 880,35 ha, tj. aż o $85,7 \%$;

- wzrostu areału gruntów ornych (głównie upraw wielkoobszarowych) nieobjętych zasięgiem urządzeń melioracyjnych o 444488,40 ha, tj. o $5,79 \%$;

- spadku powierzchni mozaikowych systemów upraw i działek o 880354,68 ha, tj. aż o 50,58\%;

- wzrostu powierzchni lasów iglastych o 620 583,20 ha, tj. o 12,4\%, lasów mieszanych o 249560,64 ha, tj. o 11,29\%², a także lasów i zbiorowisk krzewiastych „w stanie zmian” (w stadiach sukcesji) o 347 332,46 ha, tj. aż o $189,46 \%$.

Poza wyżej wymienionymi mniejsze powierzchniowo, lecz procentowo bardzo duże zmiany dotyczyły:

- wzrostu powierzchni terenów komunikacyjnych o 13 893,20 ha, tj. o $123,79 \%$;

- wzrostu powierzchni miejsc eksploatacji odkrywkowej o 17 834,63 ha, tj. o $56,58 \%$;

- wzrostu powierzchni obszarów, na których w momencie analiz trwały różnego rodzaju budowy, o 11 963,55 ha, tj. o 181,88\%;

- rozwoju terenów sportowych i rekreacyjnych o 26018,24 ha, tj. o 79,36\%;

- wzrostu areału sadów i plantacji o 72 016,97 ha, tj. o 79,64\%;

- spadku powierzchni naturalnej i półnaturalnej roślinności rozproszonej o 15497,52 ha, tj. o $65,17 \%$;

- spadku powierzchni pogorzelisk o 2218,61 ha, tj. o 100\%.

Zmianom struktury pokrycia terenu towarzyszą zasadnicze przekształcenia w ekologii i fizjonomii krajobrazu. Najważniejsze zjawiska to:

- ekspansja terytorialna miast i rozpraszanie się zabudowy stref podmiejskich w promieniu wielu kilometrów na do niedawna niezurbanizowane tereny, upowszechnienie się bezładu przestrzennego;

2 Statystycznego wzrostu powierzchni lasów nie należy utożsamiać z zalesieniami faktycznie przeprowadzonymi w omawianym okresie. Jest on także efektem porządkowania stanu ewidencyjnego - ujawniania zalesień wykonanych we wcześniejszych latach (Wasiak, 2013). Od połowy XX w. powierzchnia lasów w Polsce wprawdzie statystycznie wzrasta, jednak równolegle rośnie także skala eksploatacji ich zasobów; osuszane są cenne przyrodniczo siedliska wilgotne i bagienne oraz gęstnieje sieć dróg utwardzonych, rozcinających ekosystemy leśne. Zasoby drzewne Polski od 1967 r. (data ich pierwszej inwentaryzacji) zwiększały się, by w latach 2008-2012 osiągnąć $2405 \mathrm{mln} \mathrm{m³}$ grubizny brutto. Jednocześnie jednak w latach 1990-2012 pozyskanie grubizny (wyręby) w Lasach Państwowych systematycznie wzrastało: z niespełna 16 mln $\mathrm{m}^{3} \mathrm{w} 1990 \mathrm{r}$., do ponad $32 \mathrm{mln} \mathrm{\textrm {m } ^ { 3 } \mathrm { w }} 2012 \mathrm{r}$., czyli ponad dwukrotnie (Wasiak, 2013). W efekcie od 2009 r. przyrost zasobów drzewnych Polski jest minimalny. 
- zasadnicza zmiana charakteru wsi - z osad o dominującej funkcji rolniczej na układy wielofunkcyjne, z jednoczesną zmianą charakteru zabudowy wiejskiej: upodabnianie się wsi do krajobrazu stref podmiejskich oraz rozpraszanie się nowej zabudowy poza tradycyjnymi strukturami osadniczymi - w otwartym krajobrazie rolniczo-leśnym;

- zanik regionalnych cech architektonicznych, urbanistycznych i ruralistycznych; unifikacja fizjonomii krajobrazu;

- rozwój sieci dróg - zasadnicza poprawa ich parametrów technicznych, połączona z masową likwidacją systemu zadrzewień przydrożnych; ogromny wzrost ruchu komunikacyjnego (hałas, zanieczyszczenia powietrza, niebezpieczeństwo kolizji); rozwój pasm zabudowy wzdłuż dróg; budowa systemu ekranów akustycznych izolujących trasy komunikacyjne od krajobrazu; postępująca fragmentacja krajobrazu oraz wzrost gęstości sieci barier ekologicznych i fizjonomicznych;

- zmniejszanie się powierzchni lub likwidacja wielu naturalnych i półnaturalnych ekosystemów, a w szczególności: oczek wodnych, starorzeczy, łęgów nadrzecznych, olsów, borów bagiennych, torfowisk (głównie wysokich i przejściowych), bagien, wilgotnych wielogatunkowych łąk, muraw kserotermicznych, muraw napiaskowych, otwartych pól piaszczystych oraz wydm itp.; ogromne przyrodnicze ubożenie krajobrazu;

- regulacja i techniczna obudowa koryt rzek połączona z wycinaniem zadrzewień przywodnych, wkraczanie coraz liczniejszej zabudowy i dróg w dna dolin rzecznych; wzrastające zagrożenie powodziowe terenów zabudowanych;

- upowszechnianie się w krajobrazie rolniczym wielu regionów wielkopowierzchniowych upraw monokulturowych; likwidacja miedz, zadrzewień i zakrzaczeń śródpolnych; spadek różnorodności biologicznej i krajobrazowej obszarów rolniczych;

- ekspansja reklam (w tym wielkopowierzchniowych billboardów) w krajobrazie miejskim, podmiejskim oraz wzdłuż dróg; narastająca agresja wizualna;

- gęstnienie systemu technicznych dominant w krajobrazie miejskim i wiejskim: wieżowce, wieże telefonii komórkowej, siłownie wiatrowe, słupy linii energetycznych itp. (Chmielewski, Tajchman, 2014).

Jednym z efektów coraz większej antropopresji są narastające konflikty przestrzenne oraz pogarszające się warunki funkcjonowania zarówno przyrody, jak i gospodarki. W 2010 r. najwięcej różnego typu obszarów konfliktowych zidentyfikowano w południowej, centralnej i zachodniej Polsce 
oraz w pasie nadmorskim (Korcelli i in., 2010). Do kluczowych problemów nasilającego się bezładu przestrzennego zaliczana jest presja urbanizacyjna na obszary chronione (rys. 1) i na korytarze ekologiczne (rys. 2) (Chmielewski, Śleszyński, Chmielewski, Kułak, 2018). Większości konfliktów przestrzennych towarzyszy także degradacja walorów fizjonomii krajobrazu (szczególnie dotkliwa w przypadku natłoku reklam - fot. 1) (Chmielewski, Chmielewski, Kułak, 2018) oraz zanik tożsamości regionalnej. Analiza danych zawartych w Raporcie KPZK PAN o kosztach chaosu przestrzennego wykazuje, że ponad 60\% mieszkańców Polski żyje w krajobrazach konfliktowych, poddanych presji bezładu przestrzennego, o obniżonych lub zdegradowanych walorach kompozycyjno-estetycznych (Kowalewski, Markowski, Śleszyński, 2018).

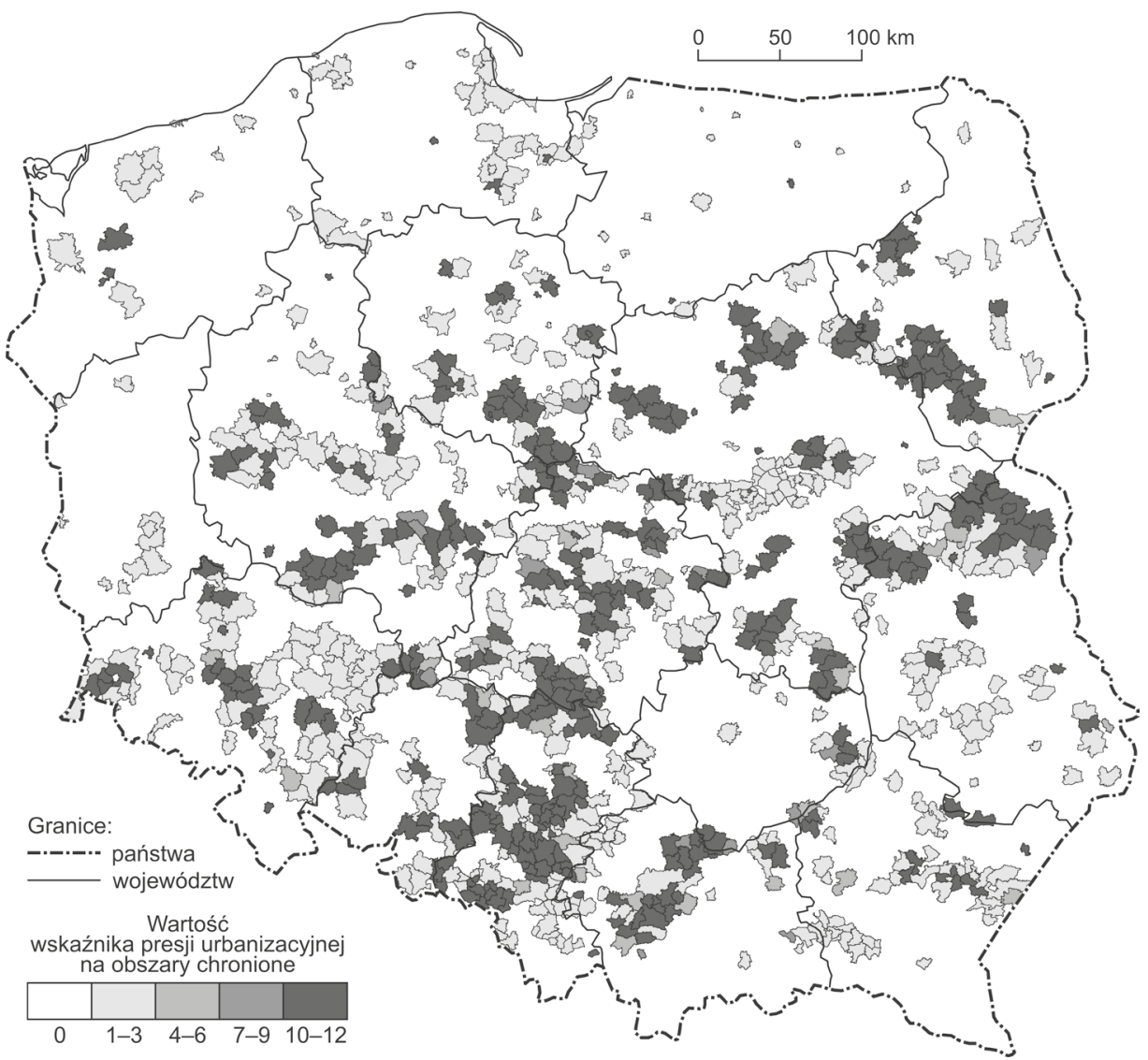

Rysunek 1. Wskaźnik (1-12 pkt) presji urbanizacyjnej na obszary chronione w gminach Źródło: Chmielewski, Śleszyński, Chmielewski, Kułak (2018) 


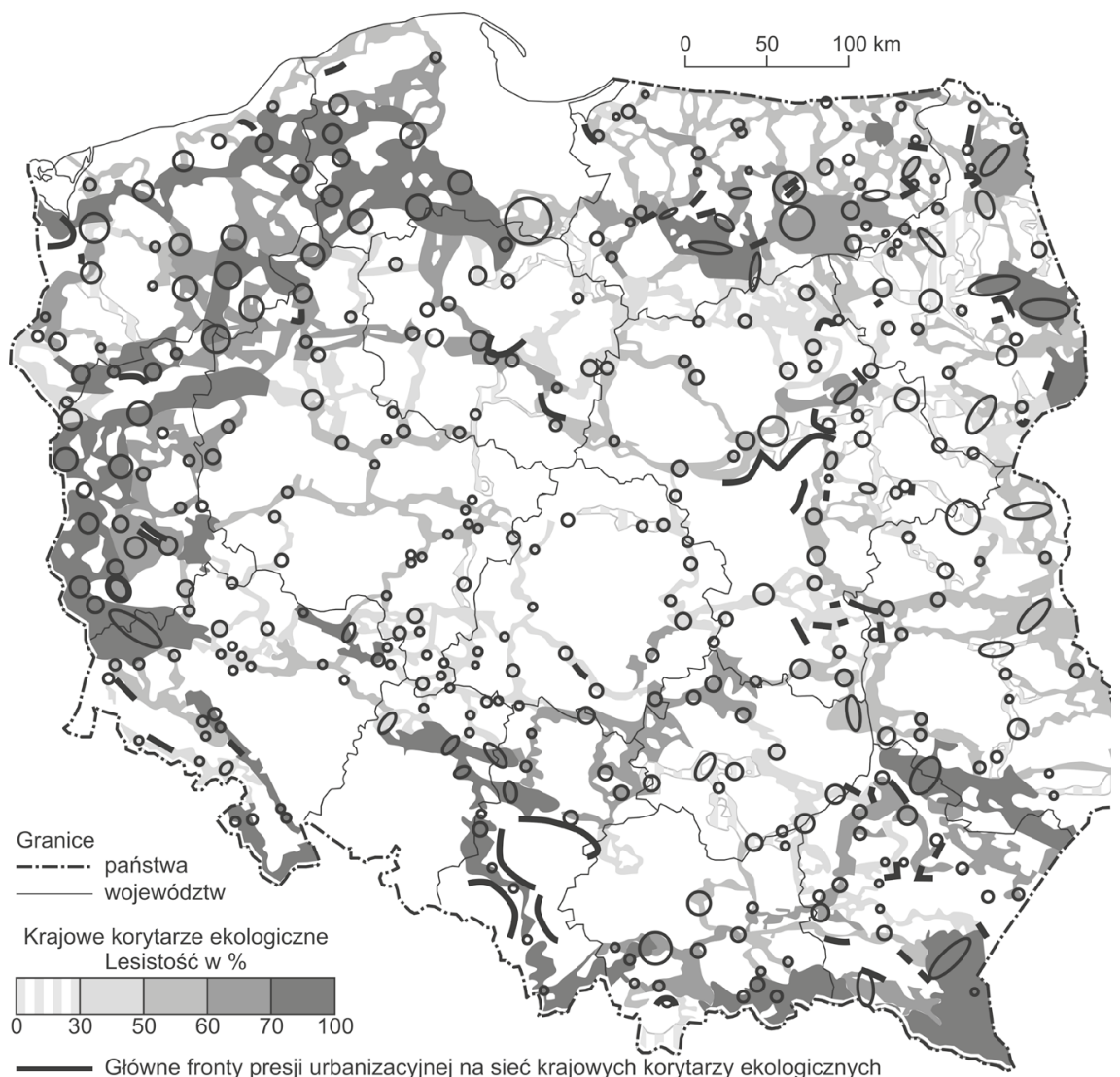

Rysunek 2. Presja urbanizacyjna na główne korytarze ekologiczne w Polsce Źródło: Chmielewski, Śleszyński, Chmielewski, Kułak (2018)

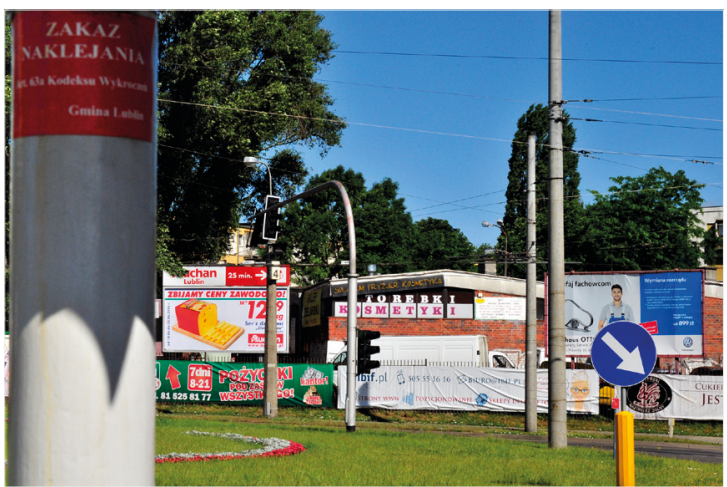

Fotografia 1. Przykład walki z natłokiem reklam w Lublinie - "Zakaz naklejania" Źródło: T.J. Chmielewski 
Wielka skala przestrzenna oraz wielokierunkowy, często drastyczny charakter zmian struktury, warunków funkcjonowania i fizjonomii krajobrazu wymagają rejestracji, okresowej oceny oraz opracowania systemu działań naprawczych.

Konsekwencją ratyfikowania przez Polskę Europejskiej Konwencji Krajobrazowej było m.in. uchwalenie Ustawy z dnia 24 kwietnia 2015 r. o zmianie niektórych ustaw w zwiazku ze wzmocnieniem narzędzi ochrony krajobrazu (2015), zwanej w skrócie Ustawa krajobrazowa. Na mocy tego dokumentu zostały wprowadzone zmiany m.in. w aktach prawnych związanych z prawem ochrony środowiska (Ustawa z dnia 27 kwietnia 2001 r. - Prawo ochrony środowiska, 2013), ochroną zabytków i opieką nad zabytkami (Ustawa z dnia 23 lipca 2003 r. o ochronie zabytków i opiece nad zabytkami, 2014), planowaniem i zagospodarowaniem przestrzennym (Ustawa z dnia 27 marca 2003 r. o planowaniu i zagospodarowaniu przestrzennym, 2015), ochroną przyrody (Ustawa z dnia 16 kwietnia 2004 r. o ochronie przyrody, 2013). Wskutek przyjęcia nowych regulacji prawnych wprowadzono m.in. obowiązek przeprowadzenia przez samorządy poszczególnych województw tzw. audytu krajobrazowego, czyli okresowego kompleksowego przeglądu i oceny stanu krajobrazów Polski. To z kolei spowodowało konieczność opracowania metodyki delimitacji, typologii i waloryzacji krajobrazów (Solon, Chmielewski, Myga-Piątek, Kistowski, 2014, 2015) oraz przygotowania bazy danych do oceny zmian zachodzących w krajobrazach, w interwałach kolejnych edycji audytu.

Zgodnie z art. 38a znowelizowanej Ustawy o planowaniu i zagospodarowaniu przestrzennym (w $2015 \mathrm{r}$. wprowadzono odnoszące się do niej zapisy Ustawy krajobrazowej):

1. Dla obszaru województwa sporządza się, nie rzadziej niż raz na 20 lat, audyt krajobrazowy.

2. Audyt krajobrazowy identyfikuje krajobrazy występujące na całym obszarze województwa, określa ich cechy charakterystyczne oraz dokonuje oceny ich wartości.

3. Audyt krajobrazowy, w szczególności:

1) określa:

a) krajobrazy występujące na obszarze danego województwa,

b) lokalizację krajobrazów priorytetowych ;

2) wskazuje lokalizację i granice:

a) parków kulturowych,

b) parków narodowych, rezerwatów przyrody, parków krajobrazowych, obszarów chronionego krajobrazu, 
c) obiektów znajdujących się na listach światowego dziedzictwa UNESCO, obszarów Sieci Rezerwatów Biosfery UNESCO (Ma) lub obszarów i obiektów proponowanych do umieszczenia na tych listach;

3) wskazuje:

a) zagrożenia dla możliwości zachowania wartości krajobrazów, o których mowa w pkt 1 lit. b, oraz wartości krajobrazów w obrębie obszarów lub obiektów, o których mowa w pkt 2,

b) rekomendacje i wnioski dotyczące kształtowania i ochrony krajobrazów, o których mowa w pkt 1 lit. b oraz krajobrazów w obrębie obszarów ub. obiektów, o których mowa w pkt 2, w szczególności poprzez wskazanie obszarów, które powinny zostać objęte formami ochrony przyrody, o których mowa w art. 6 ust. 1 pkt 3, 4 i 9 ustawy z dnia 16 kwietnia 2004 r. o ochronie przyrody (Dz.U. z 2013 r. poz. 627 , z późna. zm.),

c) lokalne formy architektoniczne zabudowy w obrębie krajobrazów, o których mowa w pkt 1 lit. b.

$[\ldots]$

6. Rada Ministrów określi, w drodze rozporządzenia:

1) stosowaną przy sporządzaniu audytów krajobrazowych klasyfikację krajobrazów opracowaną w oparciu w szczególności o takie kryteria jak charakter dominujących w krajobrazie czynników, rzeźba terenu i pokrycie terenu;

2) sposób oceny zidentyfikowanych krajobrazów oraz wskazywania krajobrazów priorytetowych;

3) sposób uwzględnienia w audycie krajobrazowym obiektów, w tym krajobrazów, wpisanych na listę światowego dziedzictwa UNESCO, obszarów Sieci Rezerwatów Biosfery UNESCO (MaB), parków narodowych, rezerwatów i innych form ochrony przyrody wskazanych w art. 6 formy ochrony przyrody ust. 1 pkt 1-9 ustawy z dnia 16 kwietnia 2004 r. o ochronie przyrody, obiektów wskazanych w art. 6 zabytki objęte ochrona i opiekq ust. 1 pkt 1 ustawy z dnia 23 lipca 2003 r. o ochronie zabytków i opiece nad zabytkami;

4) szczegółowy zakres i metodologię audytu krajobrazowego [...] (Ustawa $z$ dnia 27 marca 2003 r. o planowaniu i zagospodarowaniu przestrzennym, 2015).

Według instrukcji metodycznej, opracowanej przez zespół ekspertów (Solon, Chmielewski, Myga-Piątek, Kistowski, 2014, 2015), tok prac nad audytem krajobrazowym powinien być podzielony na następujące etapy:

1. Podział województwa na krajobrazy lokalne.

2. Przeprowadzenie klasyfikacji krajobrazów lokalnych województwa (instrukcja przewiduje ich generalny podział na 3 grupy, 14 typów i 47 podtypów). 
3. Sporządzenie listy charakterystycznych i wyróżniających się cech obszarów i obiektów, które będą oceniane w poszczególnych krajobrazach lokalnych (np.: charakterystyczne formy ukształtowania i pokrycia terenu; tekstura krajobrazu - stopień rozdrobnienia i charakterystyczny układ form pokrycia terenu; przyrodnicze obszary i obiekty chronione; typy siedlisk przyrodniczych - wodnych, leśnych, nieleśnych; zabytkowe układy granic i kompozycje przestrzenne - ruralistyczne, urbanistyczne, parkowe; zespoły i obiekty zabytkowe; unikatowa tożsamość miejsca; systemy komunikacji; obszary zdegradowane i obiekty destrukcyjne itp.).

4. Waloryzacja krajobrazów lokalnych (w skali od 1 do 12 punktów).

5. Ocena zagrożeń krajobrazu (w skali od 1 do 12 punktów).

6. Sumaryczna ocena stanu krajobrazu i delimitacja krajobrazów priorytetowych.

7. Sformułowanie wytycznych (rekomendacji i wniosków) dotyczących ochrony i kształtowania krajobrazów województwa.

Stopień szczegółowości wszystkich analiz należy dostosować do skali mapy 1:50 000 lub dokładniejszej. Kluczowy zasób powinny stanowić georeferowane (odniesione do układu współrzędnych) przestrzenne dane numeryczne, obejmujące mapy wektorowe (z zasobem bazodanowym) i rastrowe oraz dane teledetekcyjne (głównie ortofotomapy). Konieczność zgromadzenia danych dotyczy przede wszystkim pierwszego, drugiego, trzeciego oraz piątego etapu realizacji audytu krajobrazowego. Na pozostałych etapach wcześniej zgromadzone i przetworzone informacje będą podlegać dalszym analizom i ocenom, a zbieranie kolejnych danych zewnętrznych nie będzie konieczne (Solon, Chmielewski, Myga-Piątek, Kistowski, 2015).

\section{Problemy związane z przeprowadzeniem pierwszej edycji audytu krajobrazów w Polsce}

Choć instrukcja metodyczna audytu została opracowana i przyjęta przez Generalną Dyrekcję Ochrony Środowiska w 2014 r., a Ustawę krajobrazowa uchwalono w 2015 r., to rozporządzenie wykonawcze w sprawie sporządzania audytów krajobrazowych ukazało się dopiero w styczniu 2019 r. (Rozporządzenie, 2019). W 2015 r. większość urzędów marszałkowskich ogłosiła przystąpienie do opracowywania audytów, zakładając, że zostaną one wykonane przez pracowników wojewódzkich biur planowania przestrzennego lub stosownych departamentów urzędu. Nie dysponując jednak rozporządzeniem wykonawczym do Ustawy, samorządy większości 
województw przez cztery lata nie podejmowały dalszych działań, zmierzających do przeprowadzenia audytu. Tylko w kilku województwach (np. w pomorskim i wielkopolskim) urzędy marszałkowskie zleciły zespołom specjalistów z wyższych uczelni przeprowadzenie delimitacji i klasyfikacji krajobrazów lokalnych, występujących w tych regionach, zgodnie z metodyką opisaną w instrukcji audytu z 2014 r.

W Rozporzadzeniu Rady Ministrów z dnia 11 stycznia 2019 r. w sprawie sporzadzania audy tów krajobrazowych powtórzono zdecydowaną większość zapisów instrukcji z 2014 r. Doprecyzowana została struktura dokumentu audytowego (1 - część opisowa i tabelaryczna; 2 - część graficzna - zestaw map w skali 1 : 50 000, a w przypadku zespołów o cennych lokalnych formach architektonicznych w skali $1: 2000 ; 3$ - cześć dokumentacyjna, zawierająca opis zastosowanych metod, opis przebiegu przeprowadzonych konsultacji społecznych, informacje o przeprowadzonych badaniach ankietowych oraz inne niż w części pierwszej zestawienia tabelaryczne). W załącznikach do Rozporzadzenia zawarto skrócony i nieco zmodyfikowany w stosunku do instrukcji z 2014 r. opis wykorzystanych metod wraz ze wzorami obowiązujących tabel. Ważną różnicą w stosunku do instrukcji było dodanie do zakresu audytu jeszcze jednego zadania: „W audycie krajobrazowym wskazuje się obszary zabudowane wyróżniające się lokalną formą architektoniczna, w podziale na kategorie zabudowy, a ich granice przedstawia się w formie graficznej na mapach" (Rozporządzenie, 2019). Skalę tych map ustalono na $1: 2000$ (Rozporzadzenie, 2019).

Po ukazaniu się tego aktu normatywnego wojewodowie wyznaczyli marszałkom poszczególnych województw zazwyczaj trzyletni termin na wykonanie pełnych audytów. Ze względu na ogrom prac i wysoki stopień ich wyspecjalizowania, jest to termin realny, ale dość napięty, wymagający zdecydowanej mobilizacji. Taki zakres studiów i ocen krajobrazowych nie był dotychczas w wojewódzkich biurach planowania przestrzennego realizowany. Nieliczna jest także kadra specjalistów w tym zakresie, nawet na uczelniach wyższych. Studiami ekologiczno-krajobrazowymi w kontekście gospodarowania przestrzenią zajmują się jedynie specjaliści z 12 ośrodków akademickich $\mathrm{w}$ kraju, $\mathrm{w}$ tym $\mathrm{w}$ trzech $\mathrm{z}$ nich $\mathrm{w}$ mocno ograniczonym zakresie (Kistowski, 2019). Z kolei zespołów naukowych zajmujących się klasyfikacją i oceną krajobrazów aktualnych jest w Polsce zaledwie kilka. Budzi to poważne obawy o jakość pierwszej edycji audytu krajobrazowego w Polsce, zwłaszcza przy założeniu, że w większości regionów będzie on wykonywany tylko przez wewnętrzną kadrę urzędów marszałkowskich. Wprawdzie Generalna Dyrekcja Ochrony Środowiska prowadzi szkolenia dla kadry odpowiedzialnej w urzędach marszałkowskich za 
przeprowadzanie audytu, ale kilka, lub nawet kilkanaście godzin szkolenia nie wystarczy tam, gdzie potrzebne są wiedza na poziomie specjalności studiów magisterskich oraz przynajmniej kilkuletnie doświadczenie $\mathrm{w}$ przeprowadzaniu analiz systemów krajobrazowych w skali regionalnej.

Zakończenie pierwszej edycji audytu krajobrazowego w większości województw planowane jest na 2022 r., a więc 18 lat po ratyfikowaniu przez Polskę Europejskiej Konwencji Krajobrazowej. Tymczasem powinien to być rok rozpoczynania w naszym kraju już drugiej edycji kompleksowej oceny krajobrazów, wraz z analizą zmian, które zaszły w systemach krajobrazowych Polski w dwóch minionych dekadach, i z wypracowaniem strategii kształtowania wielkoprzestrzennego środowiska życia Polaków w kolejnym interwale audytów. W ostatnich dekadach zachodzą bowiem zasadnicze zmiany w strukturze przestrzennej krajobrazu: regulacja koryt rzek; likwidacja oczek wodnych i mokradeł; niwelacja terenu; wzrost udziału wielkopowierzchniowych, monokulturowych upraw rolnych; gęstnienie sieci dróg i innych struktur liniowych (w tym ekranów dźwiękochłonnych, rowów, linii energetycznych itp.); zmiany w strukturze własności gruntów; przestrzenna „,eksplozja miast"; masowe, chaotyczne rozpraszanie się zabudowy na tereny pełniące dotychczas funkcje przyrodnicze, rolnicze i wypoczynkowe; inne niż dotychczas gabaryty form zagospodarowania; wybór odmiennych materiałów budowlanych i nawierzchni; nasycanie przestrzeni publicznej agresywnymi wizualnie reklamami itp. Procesom tym towarzyszą ogromne przemiany $w$ fizjonomii krajobrazu, np. tereny zajmowane dla potrzeb systemów komunikacji są tak rozległe, że w klasyfikacji krajobrazów aktualnych tworzą nowy podtyp: krajobrazy komunikacyjne, a przy tym wyglądają niemal tak samo we wszystkich regionach kraju (fot. 2). Jednocześnie zanikają (w wielu przypadkach już ostatnie) pozostałości regionalnego stylu architektonicznego i wyróżników tożsamości miejsca (Krysiak, Majchrowska, Papińska, 2018) (fot. 3).

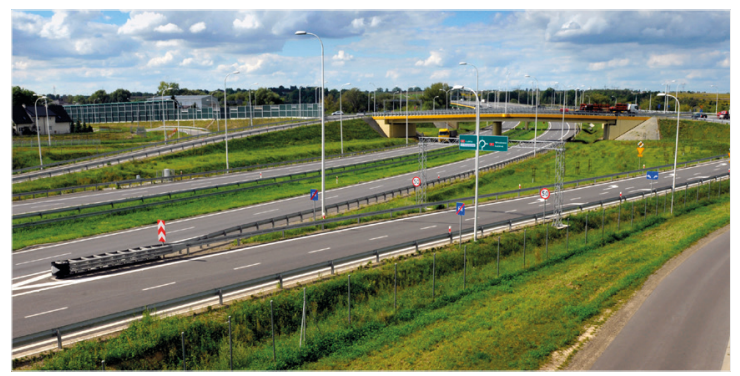

Fotografia 2. Fragment obwodnicy komunikacyjnej Lublina Źródło: fot. T.J. Chmielewski 


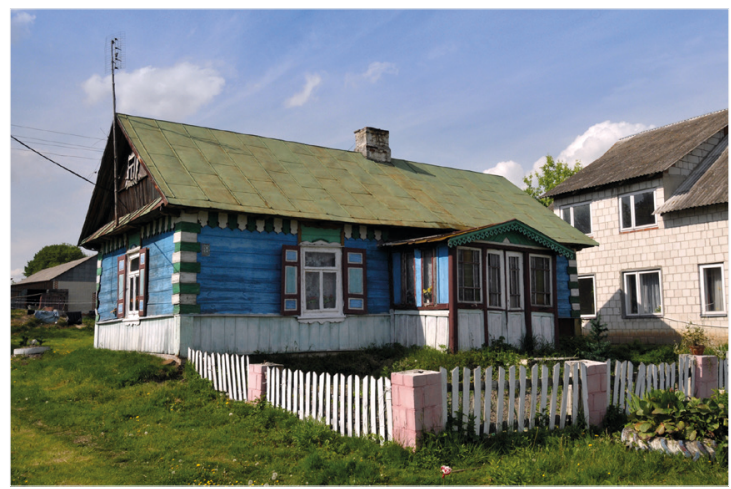

Fotografia 3. Architektura regionalna na Roztoczu Zachodnim jako wyróżnik tożsamości regionu wypierany przez zunifikowane formy zabudowy wiejskiej i podmiejskiej Źródło: fot. T.J. Chmielewski

\section{Oceny i oczekiwania społeczne dotyczące jakości krajobrazu}

W Europejskiej Konwencji Krajobrazowej duży nacisk położony jest na potrzebę identyfikacji i klasyfikacji aktualnych krajobrazów Europy oraz na udział społeczności lokalnej w ocenie ich jakości. W dokumencie tym zwraca się także uwagę na potrzebę uwzględniania oczekiwań społecznych dotyczących jakości i tożsamości krajobrazów różnych regionów $\mathrm{w}$ procesie kształtowania zagospodarowania przestrzennego. W Europie szczególną rangę tym zagadnieniom nadano dotychczas przede wszystkim w Wielkiej Brytanii, gdzie proces zarówno eksperckiej, jak i społecznej oceny jakości krajobrazu (Landscape Character Assessment) jest powszechnie wdrażany, a jego wyniki obowiązkowo brane pod uwagę w rozwoju zagospodarowania przestrzennego (Tudor, 2014). W Wielkiej Brytanii i kilku innych krajach pracom tym towarzyszą liczne badania naukowe nad społeczną percepcją różnych krajobrazów aktualnych oraz nad ich oddziaływaniem na samopoczucie i aspiracje życiowe mieszkańców. Jednocześnie prowadzona jest szeroka edukacja krajobrazowa społeczeństw (Nijnik, Zahvoyska, Nijnik, Ode, 2008).

Badania naukowe nad społeczną percepcją i oceną jakości krajobrazów są w Polsce jeszcze stosunkowo nieliczne, a zebrane dane - fragmentaryczne i rozproszone. Przegląd wyników tych badań daje obraz zróżnicowanego - od umiarkowanego do niskiego - poziomu społecznej 
świadomości znaczenia jakości krajobrazu dla poczucia komfortu życia (Solon, Regulska, 2018).

W prowadzonych przez zespół J. Solona badaniach nad potencjałem świadczeń ekosystemowych w krajobrazie ziemi augustowskiej (Solon i in., 2017) ankietowani mieszkańcy i turyści za kluczowe wartości i „dobrodziejstwa" krajobrazu tego regionu uznali:

- walory widokowe (trzecie miejsce w ogólnym rankingu wszystkich typów świadczeń ekosystemowych; 29,5\% respondentów);

- możliwość uprawiania różnych form rekreacji (miejsce piąte; 28,7\% badanych);

- korzystne warunki do odpoczynku i relaksu (miejsce siódme; 25,1\% respondentów);

- korzystny wpływ krajobrazu na zdrowie fizyczne i psychiczne (miejsce ósme; 19,1\% ankietowanych).

Z badań nad percepcją i oceną przemian krajobrazu kulturowego wsi, prowadzonych przez zespół E. Malinowskiej i J. Lechnio na Mazowszu, wynika, że wizualna jakość otoczenia wykraczającego poza obejście, nie ma istotnego znaczenia dla poczucia jakości życia mieszkańców. Tradycyjny krajobraz wiejski Mazowsza traktuje się jak synonim zacofania, a ewolucja charakteru zagospodarowania terenu w kierunku pseudomiejskim jest powszechnie akceptowana (Malinowska, Lechnio, 2018).

Z kolei wyniki badań prowadzonych przez M. Konopskiego w 71 gminach na Podlasiu wykazały, że wspólnym, najczęściej wymienianym atrybutem krajobrazowym, wyróżniającym ten region w percepcji jego mieszkańców są przydrożne krzyże i kapliczki (fot. 4). Natomiast zaskakująco niską rangę w opinii lokalnej społeczności uzyskała charakterystyczna

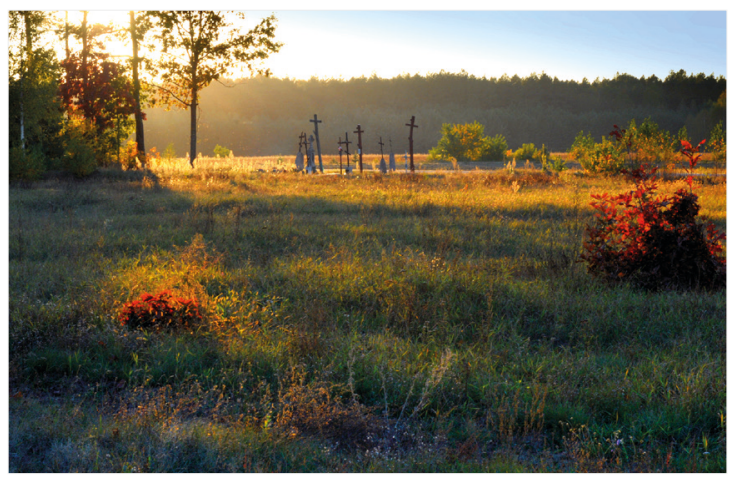

Fotografia 4. Wyróżnik krajobrazu kulturowego Podlasia - wiejski prawosławny cmentarzyk Źródło: T.J. Chmielewski 
wiejska architektura drewniana, dla turystów spoza regionu będąca jednym z kluczowych wyróżników krajobrazu kulturowego Podlasia (Konopski, 2018).

W Polsce pierwsze badania nad oczekiwaniami społecznymi dotyczącymi pożądanej jakości krajobrazu przeprowadzono w 2008 i 2010 r. pod kierunkiem T.J. Chmielewskiego. W projekcie z 2010 r. wzięło udział 120 studentów architektury, architektury krajobrazu oraz ekologii krajobrazu z 4 polskich uczelni państwowych, zlokalizowanych w dużych miastach różnych regionów Polski (Chmielewski, Sowińska, 2008; Chmielewski, Śliwczyńska, 2010). Praca studentów polegała na napisaniu krótkiego, osobistego eseju pt. „W jakim krajobrazie chciałbym żyć?”. W tych pracach wśród szczególnie pozytywie ocenianych, a zarazem pożądanych cech krajobrazu, czołowe miejsca zajęły: naturalność i jednocześnie różnorodność form ukształtowania oraz pokrycia terenu na rozległym obszarze; harmonia kompozycji przestrzennej, połączona z obecnością otwarć i panoram widokowych; wyrazistość i spójność stylu architektury (zarówno historycznego, jak i regionalnego); unikatowa tożsamość miejsca wynikająca ze wspólistnienia co najmniej dwóch wyżej wymienionych cech. Z kolei jako szczególnie negatywne ocenione zostały następujące cechy krajobrazu: obecność form niebezpiecznych, agresywnych; zanieczyszczenia środowiska; zły stan techniczny; brud; chaos przestrzenny (zwłaszcza połączony z zatłoczeniem i hałasem); brzydota i agresywność form zagospodarowania (w tym reklam); ciasnota; natłok różnych form zagospodarowania; występowanie licznych barier (ogrodzeń, przesłon itp.)

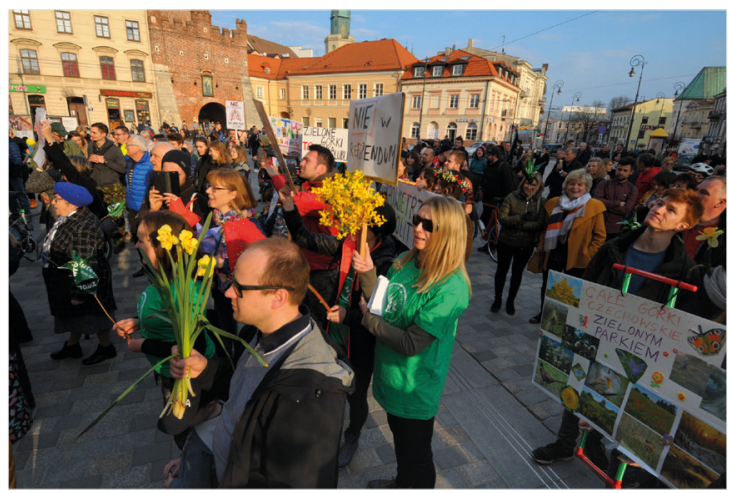

Fotografia 5. Manifestacja mieszkańców Lublina protestujących pod ratuszem

przeciwko planom zabudowy Górek Czechowskich

- cennego zespołu przyrodniczo-krajobrazowego

Źródło: T.J. Chmielewski 
i brak otwartych przestrzeni na znacznym obszarze; brak zieleni, kameralnych usług, miejsc schronienia i odpoczynku.

O wzrastającej presji społecznej dotyczącej potrzeb skutecznej ochrony cennych krajobrazów przed dewastacją świadczą m.in. petycje składane do władz samorządowych oraz uliczne manifestacje mieszkańców (fot. 5). Dlatego samorządy lokalne muszą przewidzieć szeroki udział miejscowej ludności w procesie audytu zamieszkiwanych przez nich krajobrazów.

\section{Podsumowanie i wnioski}

Krajobraz jest wielkoprzestrzennym środowiskiem naszego życia, świadectwem historii, zasobności, wiedzy i umiejętności mieszkańców danego obszaru, kształtuje naszą tożsamość, wpływa na samopoczucie i zdrowie. Dlatego o jakość krajobrazu należy dbać, podobnie jak o własne mieszkanie, ogród, miejsce pracy i wypoczynku.

W ostatnich dziesięcioleciach zaszły ogromne zmiany w strukturze przestrzennej i fizjonomii krajobrazu. Często są one niekorzystne dla ładu przestrzennego i estetyki przestrzeni. Dlatego zmiany te powinny być sumiennie rejestrowane i okresowo oceniane, wyniki tych ocen zaś - wykorzystane przy opracowywaniu strategii rozwoju poszczególnych regionów oraz ochrony ich dziedzictwa przyrodniczego i kulturowego.

Wykonywanie takich ocen jest zalecane zgodnie z Europejska Konwencja Krajobrazowa, przyjętą przez Radę Europy w 2000 r. W Polsce formalnoprawne podstawy ich przeprowadzenia określone zostały dopiero 15 lat później, w tzw. Ustawie krajobrazowej z 2015 r., ale szczegóły zakresu i metodyki tych ocen ustalono dopiero w 2019 r. w Rozporzadzeniu Rady Ministrów w sprawie sporządzania audytów krajobrazowych. W przeprowadzaniu audytu krajobrazów Polska ma więc znaczące opóźnienie w stosunku do wielu krajów Europy.

Analizy naukowe społecznej percepcji i oceny jakości krajobrazów są w Polsce jeszcze stosunkowo nieliczne i wymagają znaczącej intensyfikacji. Z przeglądu dotychczasowych wyników tych badań wyłania się obraz zróżnicowanego - od umiarkowanego do niskiego - poziomu społecznej świadomości znaczenia jakości krajobrazu dla ogólnego komfortu życia jego użytkowników. Konieczne jest więc rozwijanie szerokiej edukacji krajobrazowej społeczeństwa.

Zakończenie pierwszej edycji audytu krajobrazowego w większości województw w Polsce planowane jest na 2022 r. Prace te powinny być 
realizowane jak najintensywniej nie tylko przez kadry urzędów marszałkowskich, ale także z dużym udziałem zespołów ekspertów z wyższych uczelni oraz przedstawicieli społeczności lokalnych.

\section{Bibliografia}

Bernat, S. (2008). Dźwięk w krajobrazie jako przedmiot badań interdyscyplinarnych. Prace Komisji Krajobrazu Kulturowego PTG, 11, 1-326.

Bernat, S. (2017). Krajobraz a zdrowie. Lublin: Uniwersytet Marii Curie-Skłodowskiej.

Bezek, P., Mikóls, Z., Izakovičowá, Z. (2010). Atlas of representative geo-ecosystems of Slovakia. Bratislava: Slovak Academy of Science.

Bogdanowski, J. (1976). Kompozycja i planowanie w architekturze krajobrazu. WrocławWarszawa-Kraków-Gdańsk: Zakład Narodowy im. Ossolińskich, Wydawnictwo PAN.

Cassatella, C., Peano, A. (red.) (2011). Landscape indicators: Assessing and monitoring landscape quality. Dordrecht-Heidelberg-Londyn-Nowy Jork: Springer.

Chmielewski, Sz., Chmielewski, T.J., Kułak, A. (2018). Presja wizualna jako problem audytu krajobrazowego. Lublin: Wydawnictwo Uniwersytetu Przyrodniczego.

Chmielewski, T.J. (2008). Zmierzając ku ogólnej teorii systemów krajobrazowych. W: T.J. Chmielewski (red.), Problemy ekologii krajobrazu. Tom XXI. Struktura i funkcjonowanie systemów krajobrazowych: meta-analizy, modele, teorie i ich zastosowania (s. 93-110). Lublin: Wydawnictwo Print 6.

Chmielewski, T.J. (2012). Systemy krajobrazowe: struktura, funkcjonowanie, planowanie. Warszawa: Wydawnictwo Naukowe PWN.

Chmielewski, T.J., Sowińska, B. (2008). Social expectations concerning landscape quality objectives for the Roztocze - Solska Forest region. Teka of the Commission of Protection and Formation of Natural Environment, 5, 41-49.

Chmielewski, T.J., Śliwczyńska, E. (2010). „What landscape would you like to live in?” Expectations of young landscape designers in Poland. Teka (Archives) of the Commission of Protection and Formation of Natural Environment, 7, 35-47.

Chmielewski, T.J., Tajchman, K. (2014). Polityka krajobrazowa Polski w świetle Europejskiej Konwencji Krajobrazowej i oczekiwań społecznych. W: Z. Mirek, A. Nikel (red.), Ochrona przyrody w Polsce wobec współczesnych wyzwań cywilizacyjnych (s. 179-186). Kraków: Wydawnictwo Komitet Ochrony Przyrody PAN.

Chmielewski, T.J., Chmielewski, Sz., Kułak, A. (2019). Percepcja i projekcja krajobrazu. Przeglad Geograficzny, 91 (3), 365-384.

Chmielewski, T.J., Myga-Piątek, U., Solon, J. (2015). Typologia aktualnych krajobrazów Polski. Przeglad Geograficzny, 87 (3), 377-408.

Chmielewski, T.J., Śleszyński, P., Chmielewski, Sz., Kułak, A. (2018). Ekologiczne i fizjonomiczne koszty bezładu przestrzennego. Warszawa: Instytut Geografii i Przestrzennego Zagospodarowania PAN.

Chmielewski, T.J. (red.) (2015). Klasyfikacje i oceny krajobrazów Polski drugiej dekady XXI wieku. Problemy Ekologii Krajobrazu, XL, 1-231.

Degórski, M., Ostaszewska, K., Richling, A., Solon, J. (2014). Współczesne kierunki badań krajobrazowych w kontekście wdrażania Europejskiej Konwencji Krajobrazowej. Przeglad Geograficzny, 86 (3), 295-316. 
European Landscape Convention (2000). Pobrane z: www.coe.int/europeanlandscapeconvention (9.09.2019).

Fairclough, G., Macinnes, L. (2003). Landscape Character Assessment. Guidance for England and Scotland. Topic paper 5 - Understanding Historic Landscape Character. The Countryside Agency, Scottish Natural Heritag.

Humboldt, A. (1849). Kosmos, czyli rys fizyczny opisu świata. Tom 1. Pobrane z: http://portalwiedzy.onet.pl/57515 (12.11.2010).

Jones, M., Stenseke, M. (red.) (2011). The European Landscape Convention. Challenges of participation. Dordrecht-Heidelberg-Londyn-Nowy Jork: Springer.

Kistowski, M. (2019). Kierunki polskich zastosowań ekologii krajobrazu w gospodarowaniu przestrzenią po 1982 r. Przeglad Geograficzny, 91 (1), 7-39.

Konopski, M. (2018). Rola krajobrazu w percepcji społecznej regionu. Przykład Podlasia. W: J. Solon, E. Regulska (red). Krajobraz w percepcji społecznej. Abstrakty referatów i posterów (s. 30-31). Warszawa: Polska Asocjacja Ekologii Krajobrazu, Instytut Geografii i Przestrzennego Zagospodarowania PAN.

Korcelli, P., Degórski, M., Drzazga, D., Komornicki, T., Markowski, T., Szlachta, J., Węcławowicz, G., Zaleski, J., Zaucha, J. (2010). Ekspercki projekt Koncepcji Przestrzennego Zagospodarowania Kraju. Studia KPZK PAN, 128, 1-169.

Kowalewski, A., Markowski, T., Śleszyński, P. (red.) (2018). Studia nad chaosem przestrzennym. Studia KPZK PAN, 182 (2), 5-9.

Krysiak, S., Majchrowska, A., Papińska, E. (red.) (2018). Współczesne przemiany krajobrazów wiejskich i podmiejskich. Problemy Ekologii Krajobrazu, 46.

Malinowska, E., Lechnio, J. (2018). Zmiany krajobrazu kulturowego wsi mazowieckiej w percepcji mieszkańców. W: J. Solon, E. Regulska (red.), Krajobraz w percepcji społecznej. Abstrakty referatów i posterów (s. 38-39). Warszawa: Instytut Geografii i Przestrzennego Zagospodarowania PAN.

Malinowska, E., Lewandowski, W., Harasimiuk, A. (red.) (2004). Geoekologia i ochrona krajobrazu. Leksykon. Warszawa: Wydawnictwo Uniwersytetu Warszawskiego.

Moss, M.R., Milne, R.J. (red.) (1999). Landscape synthesis: Concepts and applications. Ontario, Canada: University of Guelph; Poland: University of Warsaw.

Mücher, C.A., Clijn, J.A., Wascher, D.M., Schaminée, J.H.J. (2010). A new European Landscape Classification (LANDMAP): A transparent, flexible and user-oriented methodology to distinguish landscapes. Landscape \& Urban Planning, 10, 87-103.

Myczkowski, Z. (2003). Krajobraz wyrazem tożsamości w wybranych obszarach chronionych $w$ Polsce. Kraków: Politechnika Krakowska.

Naguè, J., Sala, P. (2006). Prototype Landscape Catalogue: conceptual, methodological and procedural bases for the preparation of the Catalan Landscape Catalogues. Observatori del Paisatge, Olot and Barcelona, 1-34.

Nijnik, M., Zahvoyska, L., Nijnik, A., Ode, A. (2008). Public evaluation of landscape content and change: Several examples from Europe. Land Use Policy (Elsevier), 26, 77-86.

Ostaszewska, K. (2002). Geografia krajobrazu. Warszawa: Wydawnictwo Naukowe PWN.

Pietrzak, M. (1998). Syntezy krajobrazowe-zatożenia, problemy, zastosowania. Poznań: Bogucki Wydawnictwo Naukowe.

Rozporzadzenie Rady Ministrów z dnia 11 stycznia 2019 r. w sprawie sporządzania audytów krajobrazowych. Dz.U. 2019, poz. 394.

Skalski, J.A. (2007). Analiza percepcyjna krajobrazu, jako działalność twórcza, inicjujaca proces projektowania. Warszawa: Wydawnictwo Szkoły Głównej Gospodarstwa Wiejskiego w Warszawie. 
Solon, J., Chmielewski, T.J., Myga-Piątek, U., Kistowski, M. (2014). Przygotowanie opracowania pt. "Identyfikacja i ocena krajobrazów - metodyka oraz główne założenia”. Zadanie III.1. Opracowanie szczegótowej instrukcji postępowania, prowadzacej wykonawcę audytu od rozpoczęcia prac do petnego zakończenia. Wersja 02. (konsultacje: Myczkowski, Z., Plit, J.). Opracowanie niepublikowane dla Generalnej Dyrekcji Ochrony Środowiska.

Solon, J., Chmielewski, T.J., Myga-Piątek, U., Kistowski, M. (2015). Identyfikacja i ocena krajobrazów Polski - etapy i metody postępowania w toku audytu krajobrazowego w województwach. Problemy Ekologii Krajobrazu, 40, 55-76.

Solon, J., Roo-Zielińska, E., Affek, A., Kowalska, A., Kruczkowska, B., Wolski, J., Degórski, J., Grabińska, B., Kołaczkowska, E., Regulska, E., Zawiska, I. (2017). Świadczenia ekosystemowe w krajobrazie młodoglacjalnym. Ocena potencjału i wykorzystania. Warszawa: Instytut Geografii i Przestrzennego Zagospodarowania PAN.

Solon, J., Regulska, E. (red.) (2018). Krajobraz w percepcji społecznej. Abstrakty referatów i posterów. Warszawa: Instytut Geografii i Przestrzennego Zagospodarowania PAN.

Tuan, Y.-F. (1979). Thought and landscape. W: D.W. Meing (red.), The interpretation of ordinary landscapes. Nowy Jork-Oksford: Oxford University Press.

Tudor, C. (2014). An approach to Landscape Character Assessment. Pobrane z: www.gov.uk/ natural-england (11.04.2016).

Ustawa z dnia 27 kwietnia 2001 r. Prawo ochrony środowiska. Dz.U. 2013, poz. 1232, z późn. zm.

Ustawa z dnia 27 marca 2003 r. o planowaniu i zagospodarowaniu przestrzennym. Dz.U. 2015, poz. 199, 443.

Ustawa z dnia 23 lipca 2003 r. o ochronie zabytków i opiece nad zabytkami. Dz.U. 2014, poz. 1446; Dz.U. 2015, poz. 397.

Ustawa z dnia 16 kwietnia 2004 r. o ochronie przyrody. Dz.U. 2013, poz. 627, z późn. zm.

Ustawa z dnia 24 kwietnia 2015 r. o zmianie niektórych ustaw w zwiazku ze wzmocnieniem narzędzi ochrony krajobrazu. Dz.U. 2015, poz. 774.

Van Eetvelde, V., Antrop, M. (2009). A stepwise multi-scaled landscape typology and characterisation for trans-regional integration, applied in the federal state of Belgium. Landscape \& Urban Planning, 91, 160-170.

Walter, H. (1964). Die Vegetation der Erde in öko-physiologischer Betrachtung. Bd. I. Die Tropischen und subtropischen Zonen. Jena: VEB Gustav Fischer Verlag.

Wasiak, A. (red.) (2013). Raport o stanie lasów w Polsce. Warszawa: Centrum Informacyjne Lasów Państwowych.

Wilgat, T. (1965). Definicja i klasyfikacja krajobrazów. W: W. Szafer (red.), Ochrona przyrody i jej zasobóww. T. 1 (s. 461-469). Kraków: Polska Akademia Nauk, Zakład Ochrony Przyrody.

Zoido, F. (2006). Basic aspects for the implementation of the European Landscape Convention in Spain. European Spatial Planning and Landscape, 84, s. 197-205.

\section{AUDYT KRAJOBRAZÓW POLSKI: GENEZA I OCZEKIWANIA}

Abstrakt: Krajobraz to wielkoprzestrzenne środowisko naszego życia. Jest świadectwem historii, zasobności, wiedzy i umiejętności mieszkańców danego obszaru. Wpływa na nasze samopoczucie, zainteresowania i formy aktywności. Człowiek coraz silniej i szybciej przekształca krajobraz, podporządkowując go swoim rosnącym potrzebom. Zmiany te dokonywane są jednak często bez oceny ekologicznych, kulturowych i społecznych skutków ich wprowadzania. Celem artykułu jest uzasadnienie potrzeby rejestrowania 
i oceny zmian zachodzących w krajobrazach Polski oraz konieczności zwracania większej uwagi na jakość krajobrazów kształtowanych dla żyjących obecnie ludzi oraz dla przyszłych pokoleń. Systematyczne wykonywanie takich ocen zaleca Europejska Konwencja Krajobrazowa, przyjęta przez Radę Europy w 2000 r. W Polsce formalnoprawne podstawy ich przeprowadzenia zostały określone w tzw. Ustawie krajobrazowej z 2015 r., a szczegóły dotyczące zakresu i metodyki tych ocen ustalono w 2019 r. w Rozporzadzeniu Rady Ministrów w sprawie sporządzania audytów krajobrazowych. Zakończenie pierwszej edycji audytu krajobrazowego w większości województw w Polsce planowane jest dopiero na 2022 r. Prace te powinny być realizowane jak najintensywniej nie tylko przez kadry urzędów marszałkowskich, ale także $\mathrm{z}$ udziałem zespołów ekspertów z wyższych uczelni oraz członków społeczności lokalnych.

Słowa kluczowe: krajobraz, przekształcenia krajobrazu, audyt krajobrazowy, jakość krajobrazu.

\title{
POLISH LANDSCAPE AUDITS: ORIGINS AND EXPECTATIONS
}

\begin{abstract}
Landscape is a large-scale spatial living environment. It gives testimony to the history, wealth, knowledge and skills of the inhabitants of a given area. It has an influence on well-being, interests and forms of activity. Human landscape modifications are rapidly increasing and growing in scale in order to satisfy social and economic needs. However, changes are often introduced without any evaluation of their ecological, cultural or social impacts. The purpose of this article is to argue for the need to register and evaluate transformations in the landscapes of Poland, as well as to pay more attention to their quality for present and future generations. Systematic assessments are recommended by the European Landscape Convention, adopted by the Council of Europe in 2000. In Poland, the formal and legal basis for such assessments was formulated through the Landscape Act of 2019 in the regulation on landscape audits. The completion of the first landscape audit in most provinces is planned for 2022. These should be conscientiously conducted not only by employees of Marshal Offices (local government), but also by teams of university experts and local communities.
\end{abstract}

Keywords: landscape, landscape transformations, landscape audit, landscape quality. 